\title{
NATIVE SPECIES FOR DEGRADED PEAT SWAMP FOREST REHABILITATION
}

\author{
Hesti L. Tata* and Sukaesih Pradjadinata \\ Forest Research and Development Center, Jalan Gunung Batu 5, Bogor, 16610, Indonesia \\ * Corresponding authors: hl.tata@gmail.com
}

\begin{abstract}
It is known that over exploitation and repeated fire caused peat swamp forest degradation. Great effort on degraded peat forest rehabilitation has been taken to minimize forest degradation. The study aimed to understand the best tree species for degraded peat swamp forest rehabilitation. The study was conducted on degraded and burnt peat swamp forest of Tumbang Nusa Forest Research area, Central Kalimantan. The study was designed in a completely randomized design, using four native species, viz. Shorea balangeran, Dyera poyphylla, Calophyllum bifflorum, and Callophyllum inophyllum. The seedlings were planted in planting space of $5 \mathrm{~m} \mathrm{x} 2.5 \mathrm{~m}$. After eight months planting, S. balangeran had the highest seedlings survival. Environmental factors, such as ground water table and precipitation, in the demo-plot are presented.
\end{abstract}

Key words: reforestation, degraded peatland, peat fire, Central Kalimantan

\section{INTRODUCTION}

Peatland is a unique ecosystem, its characteristics distinct with other ecosystems. Peatland has low acidity, low cation exchange capacity (CEC), thus low soil fertility, as it consisted of high organic matters. Peatland ecosystem is very fragile ecosystem; once it is degraded, it is hard to be restored. It is reported that degraded peatlands in Indonesia covers an area of 3.1 million ha (ICCTF 2013). This number is increasing fast during the last decade, owing to continues human activities that induces deforestation and forest degradation.

Vegetation that grow naturally in peatlands have adaptation strategy to live in a water logged, such as pneumatohore, stomatal conductance, lenti cells forms, and others (Whitten et al. 2000). Survival rate of seedlings that were planted in reforestation area depends on tree adaptation to water logged, drought and fire. Pioneer woody species that usually occur in degraded peatland are Combretocarpus rotundatus and Cratoxylum glaucum (Graham and Page 2014; Tata and Pradjadinata 2013) and Malaeuca cajuput (a fireresistant species) (Graham and Page 2014). Native species are adaptable in the peatlands ecosystem, so that they are able to grow better than other exotic species (Page et al. 2009; Joosten et al. 2012).

We conducted an experiment on early growth of native species for peat swamp forest rehabilitation, using four different native tree species in order to study early growth and survival of four native species that were grown in logged degraded peatlands.

\section{METHODS}

\section{Study Sites}

The study was conducted in a peat swamp forest of Forest Research Area Tumbang Nusa, in Central Kalimantan. The demo plots were established in a degraded peat swamp forest or shrubs. The Forest Research Area of Tumbang Nusa was consisted of dense forest cover $(4,030 \mathrm{ha})$, medium forest cover (106 ha), light forest cover (462 ha), ferns (180 ha), and shrubs (222 ha) (BPK Banjar Baru 2010).

\section{Demo Plots Establishment}

Demo plots were established in the area of 2.5 ha of shrubs on peatland of the Forest Research Area of Tumbang Nusa. Four local species, viz. Shorea balangeran ('balangeran'), Dyera polyphylla ('pantung'), Calophyllum bifflorum ('kapur naga') and Calophyllum inophyllum ('bintangur') were planted in separate block. The planting space of each species was 5 $\mathrm{m} \times 2.5 \mathrm{~m}$.

Wildings of each species were collected from the secondary forest of the Tumbang Nusa Forest Research. Preparation of seedlings was conducted in a nursery of Tumbang Nusa forest area. Mixture of sapric peat and paddy husks was used as planting media. After 1 year in the nursery, seedlings were transplanted to demo plots. The research was designed according to randomized complete design; species was used as a treatment. Number of seedlings of each species that were planted in the demo plots varied from 320 to 450 seedlings.

Early growth of stem diameter and height of each seedling was measured twice during the observation. The first and second measurement was done in four months sequence, e.g at the age of 4 and 8 months after planting (MAP). 
Environment factors, such as water table in the plot and subsidence, were measured during the observation from April to November 2014. Two Piezometers were installed in the demo plots. Water table was measured manually twice a month. A conventional tool to measure precipitation (Ombrometer) was installed near the camp of Tumbang Nusa Forest Research area. Precipitation measurement was done every day.

\section{Data Analysis}

The relative growth rate of height and diameter within 4 month were calculated based on formula of: $\mathrm{RGRH}=\operatorname{loge} \mathrm{H} 2-\operatorname{loge} \mathrm{H} 1$ and $\mathrm{RGRD}=\operatorname{loge} \mathrm{D} 2-$ loge D1

In which: RGRH = relative growth rate of height

RGRD = relative growth rate of diameter

$\mathrm{H} 1$ = height in observation 1

$\mathrm{H} 2$ = height in observation 2

D1 = diameter in observation 1

D2 = diameter in observation 2

Basic statistical data were calculated using SPSS IBM ver.22 on the growth and survival of the four seedlings at 8 MAP. Least Significant Difference (LSD) test was used as post hoc test.

\section{RESULTS AND DISCUSSION}

Survival of four species during observation is shown in Fig. 1. Up to 4 MAP, $S$. balangeran has the best survival rate $(50 \%)$ among the four species. Meanwhile in the 8 MAP, D. polyphylla has the highest survival rate $(42.1 \%)$. C. bifflorum showed the lowest survival rate during eight months observation. $S$. balangeran has high capability to regenerate fast in burned peat forests (Atmoko 2011).

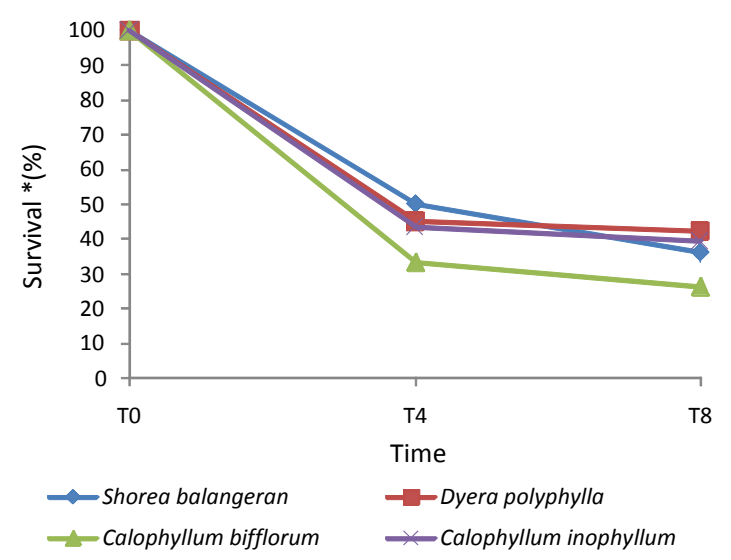

Figure 1. Survival rate of four native species planted in degraded peatland of Tumbang Nusa, Central Kalimantan

The early growth (RGRH and RGRD) of the seedlings planted in rehabilitation demo-plots were significantly affected by treatment (e.g. species). RGRH of $S$. balangeran was the highest $(0.12 \mathrm{~cm}$ month- 1$)$ compare with other three species. While D. inophyllum had the lowest RGRH (0.09 cm month-1). The RGRD of $S$. balangeran was the highest $(0.13 \mathrm{~cm}$ month- 1$)$, while $D$. pollyphylla has the lowest survival rates $(0.09$ cm month-1) (Table 1). During the observation, $C$. inophyllum less survives in the open canopy. Most seedlings of $C$. inophyllum died in the dry season

Table 1. Mean of Relative Growth Rate of Height and Diameter (RGRH and RGRD) of four species planted in demo-plot degraded peatland in Tumbang Nusa, Central Kalimantan

\begin{tabular}{lll}
\hline \multicolumn{1}{c}{ Species } & \multicolumn{1}{c}{$\begin{array}{c}\text { RGRH }(\mathbf{c m} \\
\left.\text { month }^{-1}\right)\end{array}$} & $\begin{array}{c}\text { RGRD }(\mathbf{c m} \\
\left.\text { month }^{-1}\right)\end{array}$ \\
\hline S. balangeran & $0.12(0.09) \mathrm{a}$ & $0.13(0.08) \mathrm{a}$ \\
D. polyphylla & $0.10(0.07) \mathrm{b}$ & $0.10(0.06) \mathrm{b}$ \\
C. bifflorum & $0.08(0.05) \mathrm{b}$ & $0.09(0.05) \mathrm{b}$ \\
C. inophyllum & $0.06(0.04) \mathrm{bc}$ & $0.10(0.05) \mathrm{b}$
\end{tabular}

Note: Number in parentheses is a standard deviation. Number in the same column followed by different alphabet is significantly different in the $\mathrm{p}<0.05$.

The four native species were able to grow and adaptive to the condition of degraded peatlands of Tumbang Nusa. There was no drainage or ditch established in the forest area where the demo plots were established. Hence, seedlings were occasionally submerged in the rainy season. Water table average in the demo-plots varied between $10.65 \mathrm{~cm}$ (in November) to $81.95 \mathrm{~cm}$ (in May 2014). Water table average in the demo plots is shown in Fig. 2. Hence species selection is one of important parts in peatland rehabilitation and restoration (Graham and Page 2014; Joosten et al. 2012).

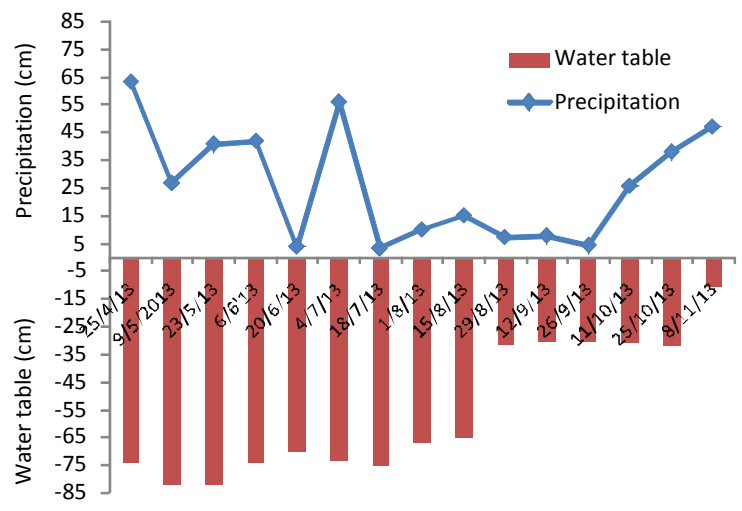

Figure 2. Water table average and precipitation in AprilOctober 2014 in the demo plot in Tumbang Nusa, Central Kalimantan.

Intact peat swamp forest is a unique ecosystem. Once it is degraded owing to human activities, such as illegal logging, drainage or canal establishment and fire, the condition of peat ecosystem has changed. The water from peat drains into the canal, so that peat will dry and subsidised. Blocking channel is necessary to be done in rehabilitation of degraded peatland and hidrology restoration. In the Tumbang Nusa case, native species that water logged resistant, light tolerant and fireresistant can be considered. Up to date, technical aspects 
of peatland rehabilitation are widely known (Graham and Page 2014; Graham et al. 2014; Banjarbaru Forestry Resarch Unit and Graham 2014; Suryadiputra et al. 2005). However, social aspect usually is a big concern in the effort of forest rehabilitation or restoration in Indonesia (Page et al. 2009; Joosten et al. 2012; Ramdani and Barkah 2011; Kettle 2012; Nawir et al. 2007; Tata 2014). Therefore, rehabilitation and/or restoration of degraded peatlands should be in an integrative manner with local people who live surroundings the areas. Improving awareness on the importance of protecting the remaining peatswamp forest and rehabilitating the degraded peatlands are as important as forest rehabilitation per se. It needs support from relevant stakeholders.

\section{CONCLUSIONS}

Among the four native peat swamp species tested in the study, $S$. balangeran showed the best survival and growth performance. C. biffllorum showed the lowest survival. Low survival rate of the four native species planted in Tumbang Nusa may be influenced by dynamics of water table in the demo-plots.

\section{ACKNOWLEDGEMENTS}

The research is financially supported by national budget research (DIPA-APBN) year 2013 of the Research and Development Centre for Forest and Conservation, the Ministry of Forestry of Indonesia. Authors acknowledge Supriatna and Rina Karokaro for field assistance.

\section{REFERENCES}

Atmoko T. 2011. Pontensi regenerasi dan penyebaran Shorea balangeran (Korth.) Burck di sumber benih Saka Kajang, Kalimantan Tengah. Jurnal Penelitian Dipterokarpa. 5(2):21-36.

Banjarbaru Forestry Resarch Unit, Graham LLB. 2014. Tropical peat swamp forest silviculture in Central Kalimantan. Kalimantan Forest and Climate Partnership. Jakarta.

BPK Banjar Baru. 2010. Peta tutupan lahan KDTK Tumbang Nusa, Kabupaten Pulang Pisau, Kalimantan Tengah. Banjarbaru. BPK Banjarbaru.

Graham LLB, Page SE. 2014. Forest restoration in degraded tropical peat swamp forest. In: Bossano M, Jalonene R, Boshier D, Gallo L, Cavers S, Bordacs S, Smith P, Loo J (eds). The State of The World's Forest Genetic Resources - Thematic Study: Genetic Considerations in Ecosystem Restoration Using Native Tree Species. FAO, Rome. pp:200-204.

Graham LLB, Susanto TW, Xaverius F, Eser E, Didie, Salahuddin AT, Mahyudi A, Applegate G. 2014. KFCP Vegetation Monitoring: Rates of change for forest characteristics and the influence of environmental conditions, in the KFCP study area. Scientific Report. Kalimantan Forests and Climate Partnership. Jakarta.

(ICCTF) Badan Litbang Perrtanian, Kementerian Pertanian, 2013. Atlas arahan pengelolaan lahan gambut terdegradasi di Pulau Sumatera. Recommendation for sustainable management of degraded peatland map. Skala 1:250.000. ICCTF-BAPPENAS-Badan Penelitian dan Pengembangan Pertanian Kementerian Pertanian. Available at: icctf.litbang.pertanian.go.id

Joosten H, Tapio-Bistrom ML, Tol S (eds). 2012. Peatlands - guidance for climate change mitigation through conservation, rehabilitation and sustainable use. 2nd edition. The Food and Agriculture Organization of the United Nations and Wetlands International. Rome.

Kettle CJ. 2012. Seeding ecological restoration of tropical forests: Priority setting under REDD+. BiolCons 154:34-41.

Nawir AA, Murniati, Rumboko, L. 2007. Forest rehabilitation in Indonesia: Where to after more than three decades? Center for International Forestry Research (CIFOR). Bogor.Indonesia. $269 p$

Page S, Hoscilo A, Wosten H, Jauhiainen J, Silvius M, Rieley J, Ritzema H, Tansey K, Graham L, Vasander H, Limin S. 2009. Restoration ecology of lowland tropical peatlands in Southeast Asia: Current Knowledge and Future Directions. Ecosystems. 12:888-905.

Ramdani A, Barkah BS. 2011. Merang REDD Pilit Project (MRPP) Persemaian dan Rehablitasi Hutan: Rehablitasi hutan rawa gambut berbasis masyarakat pada areal MRPP. MRPP-GTZ, Palembang.

Suryadiputra INN, Dohon A, Waspodo RSB, Muslihat L, Lubis IR, Hasudungan F, Wibisono ITC. 2005. A guide to the blocking of canals and ditched in conjunction with the community. Wetlands International Indonesia Programme and Wildlife Habitat Canada. Bogor.

Tata HL. 2014. Ectomycorrhiza in forest rehabilitation in Indonesia. In: $\mathrm{Ba} \mathrm{AM}$, McGuire KI, Diedhiou AG (eds). Ectomycorrhizal Symbioses in Tropical and Neotropical Forests. CRC. Boca Raton, New York.

Tata HL, Pradjadinata. 2013. Regenerasi alami hutan rawa gambut bekas terbakar dan lahan gambut bekas terbakar di Rumbang Nusa, Kalimantan Tengah dan implikasinya terhadap konservasi. Jurnal Penelitian Hutan dan Konservasi Alam. 10(3):327-342.

Whitten T, Damanik SJ, Anwar J, Hisyam N. 2000. The Ecology of Indonesia Series Vol.I: The Ecology of Sumatra. Periplus Edition (KH) Ltd. Singapore. 